\title{
Evaluation of the efficacy and safety of favipiravir and interferon compared to lopinavir/ritonavir and interferon in moderately ill patients with COVID-19: a
} structured summary of a study protocol for a randomized controlled trial

\author{
Mehdi Hassaniazad ${ }^{1}$, Ali Bazram¹, Soheil Hassanipour ${ }^{2}$ and Mohammad Fathalipour ${ }^{3,4^{*}}$ (D)
}

\begin{abstract}
Objectives: We will evaluate the efficacy and safety of favipiravir and interferon beta-1a compared to lopinavir/ ritonavir and interferon beta-1a in patients with confirmed COVID-19, who are moderately ill.

Trial design: This is a phase 3, single-center, randomized, open-label, controlled trial with a parallel-group design carried out at Shahid Mohammadi Hospital, Bandar Abbas, Iran.

Participants: All patients with age $\geq 20$ years admitted at the Severe Acute Respiratory Syndrome Departments of the Shahid Mohammadi Hospital, Bandar Abbas, Iran, will be screened for the following criteria.

Inclusion criteria:

1. Confirmed diagnosis of infection with SARS-CoV-2 using polymerase chain reaction and/or antibody tests.

2. Moderate COVID-19 pneumonia (via computed tomography and/or X-ray imaging), requiring hospitalization.

3. Hospitalized $\leq 48 \mathrm{~h}$.

4. Signing informed consent and willingness of the participant to accept randomization to any assigned treatment arm.
\end{abstract}

Exclusion criteria:

1. Underlying conditions, including chronic hepatitis, cirrhosis, cholestatic liver diseases, cholecystitis, peptic (Continued on next page)

\footnotetext{
* Correspondence: M.fathalipour@hums.ac.ir

${ }^{3}$ Department of Pharmacology and Toxicology, Faculty of Pharmacy, Hormozgan University of Medical Sciences, Bandar Abbas, Iran

${ }^{4}$ Endocrinology and Metabolic Research Center, Hormozgan University of Medical Sciences, Bandar Abbas, Iran

Full list of author information is available at the end of the article
}

C C The Author(s). 2020 Open Access This article is licensed under a Creative Commons Attribution 4.0 International License, which permits use, sharing, adaptation, distribution and reproduction in any medium or format, as long as you give appropriate credit to the original author(s) and the source, provide a link to the Creative Commons licence, and indicate if changes were made. The images or other third party material in this article are included in the article's Creative Commons licence, unless indicated otherwise in a credit line to the material. If material is not included in the article's Creative Commons licence and your intended use is not permitted by statutory regulation or exceeds the permitted use, you will need to obtain permission directly from the copyright holder. To view a copy of this licence, visit http://creativecommons.org/licenses/by/4.0/ The Creative Commons Public Domain Dedication waiver (http://creativecommons.org/publicdomain/zero/1.0/) applies to the data made available in this article, unless otherwise stated in a credit line to the data. 
(Continued from previous page)

ulcers, acute and chronic renal failure, and peptic ulcers.

2. Severe and critical COVID-19 pneumonia.

3. History of allergy to favipiravir, lopinavir/ritonavir, and interferon beta-1a.

4. Pregnancy and breastfeeding.

Intervention and comparator: Intervention group: favipiravir (Zhejiang Hisun, China) with interferon beta-1a (CinnaGen, Iran). This group will receive $1600 \mathrm{mg}$ favipiravir twice a day for the first day and 600 mg twice a day for the following 4 days with five doses of 44 mcg interferon beta-1a every other day.

Control group: lopinavir/ritonavir (Heterd Company, India) with interferon beta-1a (CinnaGen, Iran). This group will receive 200/50 mg lopinavir/ritonavir twice a day for 7 days with five doses of 44 mcg interferon beta-1a every other day.

Other supportive and routine care will be the same in both groups.

Main outcomes: The primary outcome of the trial is the viral load of SARS-CoV-2 in the nasopharyngeal samples assessed by RT-PCR after 7 days of randomization as well as clinical improvement of fever and $\mathrm{O}_{2}$ saturation within 7 days of randomization.

The secondary outcomes are the length of hospital stay and the incidence of serious adverse drug reactions within 7 days of randomization.

Randomization: Eligible patients will be allocated to one of the study arms using block randomization in a 1:1 ratio (each block consists of 10 patients). A web-based system will be used to generate random numbers for the allocation sequence. Each number relates to one of the study arms.

Blinding (masking): This is an open-label trial without blinding and placebo control.

Numbers to be randomized (sample size): A total of 60 patients will be randomized into two groups (30 patients in the intervention group and 30 patients in the control group).

Trial status: The trial protocol is version 1.0, 22 July 2020. Recruitment began on 25 July 2020 and is anticipated to be completed by 25 September 2020.

Trial registration: Iranian Registry of Clinical Trials (IRCT) IRCT20200506047323N3. Registered on 22 July 2020.

Full protocol: The full protocol is attached as an additional file, accessible from the Trials website (Additional file 1). In the interest in expediting the dissemination of this material, the familiar formatting has been eliminated; this letter serves as a summary of the key elements of the full protocol.

Keywords: COVID-19, Randomized controlled trial, Protocol, Favipiravir, Lopinavir/ritonavir, Interferon

\section{Supplementary information}

Supplementary information accompanies this paper at https://doi.org/10. 1186/s13063-020-04747-8.

Additional file 1. Full Study Protocol.

\section{Acknowledgements}

The authors would especially like to thank the assistance of Dr. Omid Safa, Ph.D.; Dr. Parivash Davoodian, M.D.; and Dr. Mehdi Farashahinejad, M.D. The authors would also like to thank all the clinicians, nurses, and medical staff who dedicate their time and effort to help us care for patients during the COVID-19 pandemic

\section{Authors' contributions}

Study design and protocol development: MH and MF. Subject recruitment and follow-up: $\mathrm{MH}$ and $\mathrm{AB}$. Data analysis: $\mathrm{SH}$. Manuscript preparation: $\mathrm{MH}$, $A B, S H$, and MF. Manuscript review and submission: $M H, A B$, and MF. The authors read and approved the final manuscript.

\section{Funding}

All the financial resources required for this trial have been provided by Hormozgan University of Medical Sciences, Bandar Abbas, Iran (grant no. 990233). The funders have no role in the trial design; the intervention procedures; the collection, evaluation, and analysis of data; the preparation and review of the final manuscript; and the decision to submit the manuscript for publication.

\section{Availability of data and materials}

The corresponding author has access to the final trial information, and the data will be available on reasonable request (contact: M.fathalipour@hums.ac. ir).

\section{Ethics approval and consent to participate}

The RCT protocol was approved by the Ethics Committee of Hormozgan University of Medical Sciences (Ethics Committee reference number: IR. HUMS.REC.1399.225) on 21 July 2020. The investigators declare the trial has received ethical approval from the appropriate ethical committee, as described above. All participants freely signed informed consent before randomization.

\section{Consent for publication}

Not applicable.

\section{Competing interests}

The authors declare that they have no competing interests.

\section{Author details}

${ }^{1}$ Infectious and Tropical Diseases Research Center, Hormozgan Health Institute, Hormozgan University of Medical Sciences, Bandar Abbas, Iran.

${ }^{2}$ Gastrointestinal and Liver Diseases Research Center, Guilan University of 
Medical Sciences, Rasht, Iran. ${ }^{3}$ Department of Pharmacology and Toxicology,

Faculty of Pharmacy, Hormozgan University of Medical Sciences, Bandar

Abbas, Iran. ${ }^{4}$ Endocrinology and Metabolic Research Center, Hormozgan

University of Medical Sciences, Bandar Abbas, Iran.

Received: 10 September 2020 Accepted: 16 September 2020

Published online: 27 October 2020

\section{Publisher's Note}

Springer Nature remains neutral with regard to jurisdictional claims in published maps and institutional affiliations.

Ready to submit your research? Choose BMC and benefit from:

- fast, convenient online submission

- thorough peer review by experienced researchers in your field

- rapid publication on acceptance

- support for research data, including large and complex data types

- gold Open Access which fosters wider collaboration and increased citations

- maximum visibility for your research: over $100 \mathrm{M}$ website views per year

At $\mathrm{BMC}$, research is always in progress.

Learn more biomedcentral.com/submissions 